\title{
小売商業の事業継承における 家族理念意識の影響に関する実証研究
}

柳

到 亨

(神戸大学)

\section{要約（アブストラクト）}

本稿では、既存研究から蓄積された議論を手がかりに、商店経営者の事業継承意志に及ぼす影響を、家族理 念意識（家族財産意識、家業意識）と経済的側面や家族要因との相互作用関係から明らかにする。本稿では、 (1)家業意識と家族従業者数の交互作用項、(2)家族財産意識と親子同居の交互作用項、そして(3)家族財産意識と 経営成果の交互作用項が、事業継承意志に影響を及ぼしていることを明らかにした。

$$
\text { キーワード }
$$

後継者難、家族財産意識、家業意識、家族従業者、親子同居、経営成果

\section{1. はじめに}

家族を重要な労働資源とする個々の商店が 多く存在し、それが日本独自の小売商業構造 を作り上げてきたが、個人商店の商店数、販 売額、従業員数が急減する近年の動向を考慮 すると、日本小売業を支えてきた「街の小売 業」が縮小している傾向がみえてきている。 日本の中小小売業が衰退産業として認識され
るなか、街の商店街や個別商店の問題では、 その核心として頻繁に「後継者難」1があげら れている。後を継ぐ者がいなくて悩む商店主 を見つけるのはそれほど難しくはない。表 1 によると、日本社会の高齢化に伴い、商店の 後継者問題は深刻さを増し、「後継者難」を多 くの小売商店経営者が問題として認識してい ることがわかる。

表1 商店街における大きな問題について 一商店街が抱えている問題点一

\begin{tabular}{|l|c|}
\hline \multicolumn{1}{|c|}{ 回答項目 } & 回答の割合 $(\%)$ \\
\hline 1. 経営者の高齢化などによる後継者難 & 67.1 \\
2. 魅力的のある店舗が少ない & 66.3 \\
3. 商店街活動への商業者の参加意識が薄い & 55.7 \\
4. 核となる店舗が少ない & 51.8 \\
5. 店舗の老巧化、陳腐化 & 48.2 \\
6. 駐車場の不足 & 37.2 \\
7. 大規模店との競合 & 36.9 \\
\hline
\end{tabular}

* 全国商店街振興組合連合会「商店街実態調査」（2003年11月）。

*複数回答のため、それぞれの合計は100にならない。

* 全国の商店街振興組合、事業共同組合、任意団体の商店街の中から8,000をサンプルとし、

有効回答数は3,455で有効回答率は $43.2 \%$ だった。 
既存研究では、家族制度 (石井 1996)、経済 的側面（田村 1981）、環境的側面（鈴木 2001） といった分析視点が日本小売業における事業 継承の分析に重要とされてきたものの、それ らの相互的関係に注目してこなかった。本稿 では、既存研究から蓄積された議論を手がか りに、商店経営者の事業継承意志に及ぼす影 響を家族理念意識と経済的側面や家族制度と の相互作用関係に注目して考察する。これは、 日本に特有な家族制度に打ける社会的関係や 理念が、日本の流通構造を生み出したという 荒川（1962）および石井（1996）の見解を採 用している。この両者の見解は、日本の商店 経営者の家族理念意識が事業継承の中心的か つ特質的要因である可能性を示している。商 人の家族制度および経済的側面が家族理念意 識にどのように依存して、商店経営者の事業 継承意志の高揚に寄与するのかを明らかにす ることが本稿の主な理論的課題である。

以上のような問題意識打よび研究課題をも つ、本稿の構成は、以下のようなものになる。 第 2 節では、後継者問題に関する既存研究の 理論的な貢献や課題を明らかにする。既存の 研究を整理することを通じて、第3節では、事 業継承モデルを構築する。これにより、本稿 が検証すべき仮説が導出される。第 4 節「仮 説検証の前の手続き」では、検証するための 手続きであるデータの収集方法抢よび諸仮説 の検証に用いられた諸变数の操作方法につい て述べる。続く第 5 節「仮説検証」では、提示 された仮説を検証し、その結果を解釈する。 第 6 節「ディスカッション」では、仮説検証 の結果をもって、理論的、実践的含意につい て整理する。最後に第 7 節では、本稿におけ る分析枠組みの外的妥当性、内的妥当性を中 心に議論する。そののち、本稿で行われた小 売業商店における事業継承に関する議論が、 小売業研究に対していかなる課題を残すのか
について考える。

\section{2. 小売業における事業継承に関する既存研究}

本節では、小売業の事業継承に関する研究 を考察するため、小売業研究において「事業 継承」の問題がどのように扱われてきたのか を、代表的な幾つかの研究を取り上げて議論 する。「事業継承」の要因は、大きく、以下の 4 つに分けてまとめることができる。

第 1 は、家族理念や規範意識が日本小売業 の再生産構造あるいは事業継承を生み出した という見解である。荒川（1962）扎よび糸園 （1975）の研究は、中小小売商店の事業継承に 関する議論を前近代的社会関係、つまり家父 長家族制度に関連付けようとしたものであっ た。これらの研究に続いて石井(1996)は、日本 小売業に打ける商人家族の家族理念が商人家 族の事業継承を促したと指摘している。そし て、こうした個々の小売商店を再生産する仕 組みが、日本小売業のマクロ構造の動態を生 み出したという。第 2 に、商人家族に打ける 「家商分離」の現象が商店の後継者問題と密接 な関連があるという見解は、石井(1996)に よって主張された。第 3 に、後継者の確保を 分析する際、商店の売上高成長の速度に注目 した研究が田村（1981）である。第 4 に、後 継者問題をもたらす原因として環境諸要因を 指摘する研究は、鈴木（2001）によって展開 されてきた。

\section{3. 小売業の事業継承実証モデルと仮説導出}

既存研究では、家族理念、商店経営特性 (家 族制度）、そして経営成果を別々の独立した要 因として考察してきたが、家族理念と商店経 営特性、家族理念と経営成果の交互効果に注 目することによって、事業継承研究の理論的 議論を深める。まず、家族理念と事業継承意 志との関係についてみていくことにする。 


\section{3-1. 家族理念}

石井（1996）は個々の商店経営および日本 小売業全体の動態に影響を与えた要因として、 商店経営者およびその家族従業者が持ってい る家業意識や家族財産を挙げている。石井 (1996)において商店経営者あるいはその家族 従業者が抱く家業意識は、日本の一般家族成 員が持つ家族理念を、「家族財産」という概念 と関連すると指摘している。「家族財産」とい うのは、「財産は、家族の特定の誰かの財産で はなく、家族全員の所有物だ」2 という意識で ある。この家族財産意識が日本家族の基本的 な規範として位置付けられている。このよう な家族理念に覆われた商店主ならびに家族従 業者は、家業意識を持つことになるという。 しかし、我々が家族理念意識を考える際には、 2 次元であることに注意を払わなければなら ない。家族理念として考えるのは、日本家族 を特徴づける基本的規範としての家族財産、 家族財産に覆われた商人家族に打ける家業意 識、これらの2つである。以上の議論から、次 のような仮説が導出される。

H1A：商店経営者の家族財産意識が高くな るにつれ、事業継承意志が高くな る。

H1B：商店経営者の家業意識が高くなるに つれ、事業継承意志が高くなる。

\section{3-2. 商店経営特性}

事業継承意志は、商店における経営特性を 規定する幾つかの要因により影響をうける。 ここで述べる商店経営特性は、第 1 に、家族 要因 (家商分離の現象)、第 2 に、商店の創業 以来の営業年数、第 3 に、商店の年間売上高 規模という 3 つ要素で把握できる。

\section{3-2-1. 家族要因}

前節で考察したように、「小売業における後 継者問題」は、「家商分離」という視点から見 直される必要があるということが石井 (1996) によって提唱された。「家商分離」とは、石井 （1996）によれば、「家族が、すでに小売商の 経営単位ではなくなってしまっている」ある いは「商売と家族とは別だ」という事態であ ると定義されている ${ }^{3}$ 。この「家商分離」の現 象は、「商売単位としての商人家族」が「消費 単位としての商人家族」への変遷することを 物語っている。「家商分離」の現象により商人 家族と商売との関わりが切り離され、具体的 例として、第 1 に、核家族化、第 2 に、商売と 住まいとの分離、これらの結果として最後に、 家族労働資源の枯渴を招く事態を挙げてい る4。順に事業継承意識に及ぼす影響の論理を 述べていこう。

第 1 に、核家族化である。石井（1996）に よれば、商店主世帯は、農林魚業世帯を除け ば他の職業の世帯規模よりも規模が大きい世 帯であったという5。この核家族化による商店 主世帯規模の縮小は、商売・経営単位として の家族の意味が失われる可能性を内包してい る。このことから、次のような仮説が導かれ る。

H2A：子供と別々に住んでいる商店経営者 より、子供と一緒に住んでいる商店 経営者のほうが、事業継承意志の度 合いがより高い。

第 2 に、商売と住まいとの分離（以下、職 住分離)である。商売と住まいが一致すると、 商人家族の生活は商売中心になり、子供も自 然に生活のなかで商売になじんでいくが、こ れとは反対の論理で、商売と住まいが分離す ると、商売よりは家族の生活や団欒を優先す 
ることになる。ゆえに、職住分離について次 の仮説が導かれる。

H2B：商住環境が分離している商店経営者 より、商住環境が一致している商店 経営者のほうが、事業継承意志の度 合いがより高い。

最後に、家族労働資源の枯渇である6。石井 （1996）は、近代家族は伝統的家族とは異な り、夫婦の愛情を基礎として婚姻を結び、家 族を形成するという 7 。当然のことながら、商 人家族の商売への関与あるいは参加が少なく なることは、後を継ぐ者の確保を難しい仕事 にさせる。家商分離の現象が小売業における 商売と商人家族との関係を切り離し、具体的 現象として核家族化、職住分離を導く。これ らの結果として商店における家族従業者密度 が下がり、商店経営者の事業継承意志を低下 させることになると思われる。ゆえに、家族 従業者数について次のような仮説が導出され る。

$\mathrm{H} 2 \mathrm{C}$ ：商店に従事する家族従業者が多くな るにつれ、商店経営者の事業継承意 志が高くなる。

\section{3-2-2. 創業以来の営業年数}

石井（1996）は、商店の歴史は家業意識 を高揚あるいは家族への使命感を高揚させる という仮説を出している (250頁)。彼は、1991 年時点における「商業統計表」調査のデータ で、創業年数が 30 年を越える商店が全体の個 人商店の約 3 割近くを占めている事実から、 商店の歴史は事業継承を促す要因の 1 つでは ないかという見解を示している。この指摘か ら、創業以来 30 年以上の営業年数を保つ個人 商店は、 2 代目あるいは3代目が商店を継いで
いることが予想される。ゆえに、創業以来の 営業年数について次のような仮説が導出され る。

H2D：創業以来の営業年数が長くなるにつ れ、商店経営者の事業継承意志が高 くなる。

\section{3-2-3. 経済的要因（規模）}

経済的側面での事業継承意志に影響を及ぼ す要因として、経営成果以外にも商店規模が あると考えられる。先行研究に打ける商店規 模を表わす指標は、販売額、従業員数、売場 面積である ${ }^{8}$ 。経済的側面での商店規模が事業 継承意志に及ぼす影響を調べる際に、これら の 3 つの商店規模を表わす変数のなかから、 年間売上高で測ることにする。商店規模は、 商人の経済的報酬を確保する資源である可能 性がある9。したがって、他の変数が一定であ ると、年間売上高という商店規模が大きい商 店のほうが、商店規模が低い商店より商店経 営者の事業継承意志の度合いは高くなると思 われる。

$\mathrm{H} 2 \mathrm{E}$ ：商店の年間売上高の規模が大きい商 店経営者ほうが、規模の小さい商店 経営者より事業継承意志の度合いが より高い。

\section{3-3. 商店経営成果}

田村（1981）によれば、後継者の確保は売 上高成長速度を維持することと深く関係する という。すなわち、後継者の確保は、売上高 成長速度の維持に依存することであり、「売 上高成長速度」は年間売上高 / 企業年齢であ る ${ }^{10}$ 。この売上高成長速度という概念に注意 してみて打こう。彼の見解から、後継者の確 保が年間売上高に比例し、企業年齢に反比例 
するということが解釈できる。これと反対に、 企業年齢が若くても、売上高が高いと、後継 者確保には好条件になる。商店の歴史が後継 者確保には反比例するということは、既に検 討した仮説とは異なるものの、売上高成長速 度が事業継承意志の考慮すべき要因であるこ とに注目させる見解である。ここで注意を払 わなければならないのは、経営成果の変動を 測る指標としての売上高の変動は、厳密な定 義では年間売上高 / 企業年齢であるが、商店 経営者が認識する年間売上高の変動とす る11。以上の議論から、経営成果について次の ような仮説が導出される。

H3：経営成果が好調になるにつれ、商店 経営者の事業継承意志が高くなる。

\section{3-4. 環境諸要因}

鈴木（2001）は、個別商店の環境諸要因の 悪化が経営の維持、あるいは継承に悪条件に なるという (52頁)。鈴木 (2001）から小売商 店を取り巻く環境諸要因は、立地条件、消費 者の需要水準、小売の技術、競争構造という 4 点でまとめることができる。環境諸要因が 個別商店に有利に働くにつれ、商店経営者の 事業継承意志が高揚するという仮説である。 ゆえに、環境諸要因について次のような仮説 が導出される。

$\mathrm{H} 4 \mathrm{~A}$ ：環境要因（立地条件、需要水準、情 報化）が商店経営に対して有利に働 くと認識するにつれ、商店経営者の 事業継承意志が高くなる。

H4B：競争環境が緩やかであると判断する につれ、商店経営者の事業継承意志 が高くなる。

\section{3-5. 家族理念と商店経営特性および家族理念 と経営成果との交互効果}

ここで提示したい理論的仮説は、第1に、商 店の経営特性（家族要因：核家族化・職住分 離・家族従業者数）が、商店経営者の家族理 念意識に依存しながら、商店経営者の事業継 承意志に影響を与えるということである。第 2 に、商店の経営成果が、商店経営者の家族理 念意識に依存しながら、商店経営者の事業継 承意志に影響を与えるということである。本 研究の分析枠組みを図 1 に示している。すな わち、第 1 に、家族要因 (核家族化 - 職住分 離・家族従業者数）はそれぞれ、家族理念意 識と相互作用しながら、商店経営者の事業継 承意志に影響を与えるということである。第 2 に、商店の経営成果と家族理念意識は相互 作用しながら、商店経営者の事業継承意志に 影響を与えることである。

\section{図1 本研究の分析枠組み}

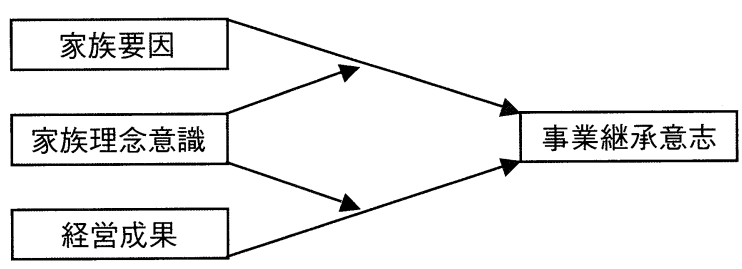

第 1 の研究課題、すなわち家族要因（核家 族化・職住分離・家族従業者数）が家族理念 意識と相互作用しながら事業継承意志に影響 を与える、という課題がどのように導き出さ れたかを検討しよう。家族理念意識の概念を 検討することからはじめて、これらの課題を 議論していくことにする。石井（1996）は、 「「家族の理念 12 に覆われた商店主ならびに家 族従業者は、家族意識ひいては一種の天職意 思をも、もつことにもなる。それは「この小 売業は、我々家族を経済的にも精神的にも支 える家業だ」」(279頁) という。ここで、家族 
理念意識の持つ経済的・精神的意味を検討し たい。

まず、精神的意味である。この精神的意味 では、家族と商売の関係を探る必要がある。 石井（1996）は、商人家族の家業意識への強 い志向を生み出す条件は、「伝統的家族」の存 在であると述べている ( 86 ～87頁)。伝統的 家族は、消費のために形成される「近代家族」 とは異なり、職住一致、拡大家族、家族従業 者の商売に対する高い関与をその特徴として いる。これらの家族と商売との深い関わりは、 当然のことながら、商人家族にとっての家業 の精神的意味合いを高めることになると思わ れる。要するに、伝統的日本家族制度の特徵 が、家業意識あるいは家族財産といった家族 理念を強化することになる。したがって、後 継者を確保するため、商店経営者の家族理念 意識が高い場合は、職住一致、拡大家族（親 子同居)、家族従業者という家族要因が持つ影 響が重要になる。すなわち、「伝統的家族」の 特徵である商人家族の商売への関与を示す家 族要因は、家族理念意識が高いときに有効な 要因になる。他方、商店経営者の家族理念意 識が低い状況では、商人家族の有り様に関係 なく、事業継承意志にはあまり影響を及ぼす ことがない。すなわち、商店経営者の家族理 念意識が低い場合には、事業継承意志を高揚 させる要因として商人家族の有り様の重要度 は低下する。

つぎに、経済的意味である。商売が家業で あると認識している商店経営者は、商売に対 してそれほど貧欲ではなく、かつ「家業の継 続性」を重視するため、有望な市場機会ある いはリスクを回避する行動を取る可能性があ る。しかし、生計のための安定した収入が得 られないと、家族にとっての家業としての経 済的意味はなくなるはずである。現在の商店 における経営成果の動向は、将来の経営成果
に対する期待感に影響を及ぼす。つまり、商 店の経営成果は、商店経営者が自身の子供に 小売業の商売という職業を継がせることを考 慮する際に重要な事項になる。経済的報酬が 保証できない商売を子供に継がせることは、 商店経営者に責任感や不安感をもたらす。商 店経営者の家族理念意識が高い場合において、 商店の後継者を確保するために経済成果の格 差が有効になる。すなわち、家族にとっての 家業としての経済的意味を考慮すると、経営 成果の動向が持つ影響は重要になると考えら れる。これとは逆に、商店経営者の家族理念 意識が低い場合には、経営成果の動向が事業 継承意志にあまり有効な要因とはならない。 なぜならば、家業の継続性を求めないため、 事業継承を高揚させる要因としての経営成果 の重要度は低下するからである。

しかし、ここで我々が注意を払うべき点は、 家族理念意識を 2 つの次元で考えなければな らない点である。すなわち、家族財産意識と 家業意識が、それぞれ事業継承意志に対する 経営成果、商店経営特性（家族要因）の有効 性にどのような影響を与えるか、という研究 課題について検証しなければならない。

$\mathrm{H} 5 \mathrm{~A}$ ：親子同居が事業継承意志に与える効 果は、商店経営者の家族財産意識が 高いほどより大きくなる。

$\mathrm{H} 5 \mathrm{~B}$ ：親子同居が事業継承意志に与える効 果は、商店経営者の家業意識が高い ほど大きくなる。

$\mathrm{H} 5 \mathrm{C}$ ：職住一致が事業継承意志に与える効 果は、商店経営者の家族財産意識が 高いほどより大きくなる。

H5D：職住一致が事業継承意志に与える効 果は、商店経営者の家業意識が高い ほどより大きくなる。

$\mathrm{H} 5 \mathrm{E}$ ：家族従業者数が事業継承意志に与え 
る効果は、商店経営者の家族財産意 識が高くなるほどより大きくなる。

$\mathrm{H} 5 \mathrm{~F}$ ：家族従業者数が事業継承意志に与え る効果は、商店経営者の家業意識が 高くなるほどより大きくなる。

$\mathrm{H} 5 \mathrm{G}$ ：商店経営成果が事業継承意志に与え る効果は、商店経営者の家族財産意 識が高いほどより大きくなる。

$\mathrm{H} 6 \mathrm{H}$ ：商店経営成果が事業継承意志に与え る効果は、商店経営者の家業意識が 高いほどより大きくなる。

このような仮説を検証するための手続きで ある、データの収集方法および諸仮説の検証 に用いられた諸変数の操作方法について次節 で述べていくことにする。

\section{4. 仮説検証のまえの手続き}

\section{4-1. 事業継承意志に影響を及ぼす変数開発}

第 3 節で述べた諸仮説には、それを構成す る概念として家族理念意識、環境要因、競争 要因、経営成果、商店経営特性、事業継承意 志があった。以下では、上記に述べた諸概念 について説明していくことにしよう。

第 1 に、商店経営者の家族理念意識という 概念を構成する指標の開発には石井（1996） の研究を参考にした。第 2 に、環境諸要因に ついては、環境要因と競争要因という $2 つ の$ 概念にわけて質問票に用いることになる。ま ず、環境要因を表わす変数として(1)立地条件、 (2)消費需要、(3)情報化などの指標を用いてい る（野口 1987 ; 鈴木 2001）。つぎに、競争要 因という指標は、田村（1981）、野口（1987）、 中野（1989）、鈴木（2001）の研究に基づいて 質問項目として提示されている。第 3 に、経 営成果という概念は、田村（1981）、野口 （1987）などの研究を参考にし、売上高、客数、 客単価、利潤という商店の経営動向を、商店
経営者はどのように認識しているのかを測定 する変数である。第 4 に、商店経営特性を表 す概念は、商店の歴史、家族要因（家族従業 者数、親子同居、職住一致)、商店の年間売上 高規模である。商店経営特性を示す要因、つ まり商店の歴史および家族要因（家族従業者 数、親子同居、職住一致）という概念の指標 は石井 (1996) の研究に基づいて開発した。な お、商店の年間売上高規模は、田村（1973）、 石井（1981）に基づいて開発した。

\section{4-2. 調査概要および指標の操作化}

2004 年 8 月に、兵庫県神戸市の商店経営者 に対して、「商店経営に関する調査」という調 查票を送付した ${ }^{13}$ 。また、この質問票調査は、 代理人を通じて各商業集積の代表者の同意を 得て、各商業集積の代表者による各商店経営 者への資料の配布および回収によって行われ た。後継者問題に関する先行研究をもとに抽 出された質問票を構成し、調査票に含まれて いる質問の中で、商店経営特性と関連する指 標以外は、すべて 5 点尺度で商店経営者の認 知を問う形式になっている。回収した質問票 のうち、記入ミスや不正回答を除く、回答に 欠損のあるものを分析から除外したため、有 効回答数は、383票 (回収率 $76.6 \%)$ となった。 
表2 概念の操作的定義

\begin{tabular}{|c|c|c|}
\hline 概念 & 次元 & 操作的定義 \\
\hline 家族理念意識 & $\begin{array}{c}\text { 家族財産意識 } \\
\text { 家業意識 }\end{array}$ & $\begin{array}{l}5 \text { 点尺度評点、1（弱） }-5 \text { (強) } \\
5 \text { 点尺度評点、1 (弱) }-5 \text { (強) }\end{array}$ \\
\hline 環境要因 & $\begin{array}{l}\text { 情報化 } \\
\text { 立地条件 } \\
\text { 需要水準 }\end{array}$ & $\begin{array}{l}\text { 5点尺度評点、1 (弱) }-5 \text { (強) } \\
5 \text { 点尺度評点、 } 1 \text { (弱) }-5 \text { (強) } \\
5 \text { 点尺度評点、 } 1 \text { (弱) }-5 \text { (強) }\end{array}$ \\
\hline 競争要因 & 競争要因 & 2指標（大型店競争十新規競争）の平均值 \\
\hline 経営成果 & 経営成果 & 4指標（売上高十利潤十顧客数十顧客単価）の平均値 \\
\hline 商店経営特性 & $\begin{array}{c}\text { 営業年数 } \\
\text { 家族従業者 } \\
\text { 親子同居 } \\
\text { 職住一致 } \\
\text { 年間売上高規模 } \\
\end{array}$ & 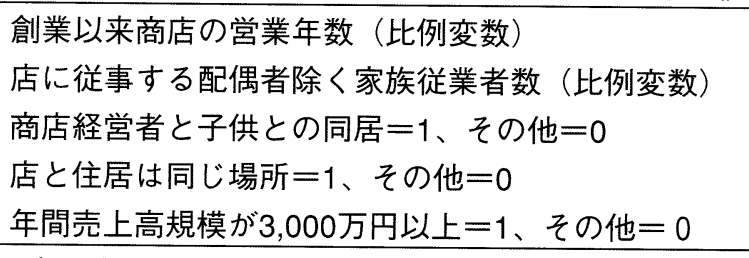 \\
\hline 事業継承意志 & 家族事業継承意志 & 5点尺度評点、1 (弱) -5 (強) \\
\hline
\end{tabular}

なお、その有効回答数のうち、事業継承意 志に影響を及ぼす諸仮説の検証には、50代以 上の商店経営者に限定 ${ }^{14}$ することになる。 50 代以上の商店経営者が回答したサンプルを もって、事業継承に関する諸仮説を検証する ことにする。なお、全体の有効回答数 (383票) のなかで、 50 代以上の商店経営者の標本数は 294 票である。神戸市の商店経営者から得た
質問票に基づいて、各变数間の関係や概念の 内部収束性を考慮し、表 2 に示すような操作 的定義を行うことができる。また分析に用い た変数の記述統計および相関関係は表 3 に示 し、複数指標で構成される変数の内的一貫性 （信頼性のデータ：Cronbachの $\alpha$ 係数）は表 3 の注にまとめているので、そちらを参照さ れたい。

表3 変数の記述統計と相関

\begin{tabular}{|l|c|c|c|c|c|c|c|c|c|c|}
\hline & 平均 & $\begin{array}{c}\text { 標準 } \\
\text { 偏差 }\end{array}$ & 1 & 2 & 3 & 4 & 5 & 6 & 7 & 8 \\
\hline 1.家業意識 & 4.38 & 1.21 & - & & & & & & & \\
\hline 2.家族財産 & 3.70 & 1.15 & $0.243 \mathrm{a}$ & - & & & & & & \\
\hline 3.需要水準 & 2.87 & 0.97 & -0.092 & 0.042 & - & & & & & \\
\hline 4.情報化 & 3.01 & 1.00 & 0.079 & $0.154 \mathrm{~b}$ & $0.199 \mathrm{a}$ & - & & & & \\
\hline 5.立地水準 & 2.39 & 1.07 & 0.008 & 0.026 & $0.239 \mathrm{a}$ & $0.235 \mathrm{a}$ & - & & & \\
\hline 6.競争要因 & 4.19 & 0.89 & $0.118 \mathrm{c}$ & 0.071 & 0.038 & $0.121 \mathrm{~b}$ & 0.016 & - & & \\
\hline 7.経営成果 & 1.97 & 22.1 & -0.06 & -0.07 & $0.195 \mathrm{a}$ & $0.171 \mathrm{a}$ & $0.278 \mathrm{a}$ & $-0.193 \mathrm{a}$ & - & \\
\hline 8.商店歴史 & 45.2 & 1.09 & $0.159 \mathrm{a}$ & $0.109 \mathrm{c}$ & 0.089 & $0.106 \mathrm{c}$ & $0.112 \mathrm{c}$ & 0.078 & -0.041 & - \\
\hline 9.家族従業者数 & 0.80 & 0.50 & $0.107 \mathrm{c}$ & 0.061 & $0.102 \mathrm{c}$ & $0.110 \mathrm{c}$ & 0.039 & 0.020 & 0.042 & $0.169 \mathrm{a}$ \\
\hline
\end{tabular}

1）cは10\%以内での統計的有意性、bは5\%以内での統計的有意性、aは $1 \%$ 以内での統計的有意性を示す.

2）総標本数は294で、変数ペアごとのサンプル数は異なる。

3）複数指標で構成される概念である経営成果、競争要因の信頼性のデータ（Cronbachの $\alpha$ 係数）は、それぞれ0.969、0.856で あった。 


\section{5. 仮説検証}

第 4 節で操作化された変数を用いて、家族 理念意識、環境諸要因 (環境要因、競争要因)、 経営成果、商店経営特性が事業継承意志にど のような因果関係を持っているのかについて 検討するため、重回帰分析が採用される。モ デル 1は、仮説 H5 を除く H1、H2、H3、H4に 関連した推計結果である。表 4 のような分析 結果を受けて、幾つかの注目すべき結果を述 べていく。第 1 に、自由調整済み決定係数の 值が、0.281というこの種の研究ではある程度 高い值をとっており、このことは、商店経営 特性が商店主の事業継承意志に影響を及ぼす という因果関係を支持する 1 つ証拠となると 考えられる。第 2 に、商店経営者の家族理念 の1つである家業意識は商店経営者の事業継 承意志に正の影響を与える有力な変数となっ

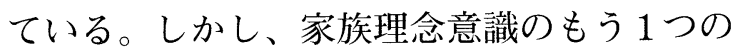
次元である家族財産意識が事業継承意志の高 揚に結びゔくという因果関係の統計的根拠は みつからない。商店経営者の家族財産意識が 事業継承意志に直接的な因果関係が確認され ないのは、家族財産意識には、「財産を相続す る」あるいは「商いを家業とする」という二 重の意味を含むかもしれないからである。し たがって、家族財産意識が高いといって、必 然的に事業継承意志が高くなるという因果関 係は示しにくいと考えられる。第 3 に、商店 経営特性のなかでは、家族従業者数、親子同 居、営業年数という変数が商店経営者の事業 継承意志の高揚に及ぼす影響が大きい。第 4 に、経営成果は、商店経営者の事業継承意志 に正の影響を与える変数であることが確認さ れた。しかし、第 5 に、商店経営特性のなか で、商住一致、年間売上高規模という変数は 事業継承意志に影響を与えるという統計的根 拠は見つからなかった。職住一致の直接の効 果が確認されなかった理由は様々推測される
が、その 1 つの理由として、商人家族の論理 や事情とは別にして、商店街の合理化活動や 外部の環境変動を通じて、商店の拡張、改装、 または土地価格の上昇が職住を分離すること に迫られたかもしれない。したがって、事業 継承意志と職住一致との因果関係を確認する ことができないと考えられる。つぎに、商店 の年間売上高規模の直接な因果関係がみられ なかったのは、商店の規模によって事業継承 意志が高揚されるのではなく、経済的側面で みるかぎりでは田村（1981）がいう商店の売 上高成長速度あるいは経営成果が事業継承意 志にもっと有効な要因であるのかもしれない。 第 6 に、環境要因のなかで、情報化は、商店 経営者の事業継承意志に正の影響を与える変 数となっているが、その他の環境要因である 需要水準、立地条件が事業継承意志に正の影 響を及ぼす因果関係は確認されなかった。

モデル2では、第 1 に、モデルのあてはまり の良さを示す自由度調整済み決定係数は、交 互作用項を除いて継承意志に関する因果関係 分析（モデル 1) の0.281 から交互作用項を含 む因果関係分析の 0.313 に改善しており、モデ ルの説明力が向上していることがいえる。第 2 に、家族従業者数と家業意識の交互作用項 が事業継承意志に $1 \%$ 水準で統計的に有意な 影響を与えている。第 3 に、経営成果と家族 財産意識の交互作用項が事業継承意志に $5 \%$ 水準で統計的に有意な影響を与えている。第 4 に、親子同居と家族財産意識の交互作用項 が、事業継承意志に $1 \%$ 水準で有意な影響を 与えている ${ }^{15}$ 。親子同居が事業継承意志に与 える効果は、家族財産意識が高いほど小さく なっていることを示している。第 5 に立て られた交互作用項に関する仮説のなか、5つ が支持されなかった。すなわち、家族財産に 関しては、家族従業者数との交互作用効果し か確認できず、家業意識に関しては、親子同 
居、経営成果との交互作用効果しか確認でき なかった。第6に、家業意識、親子同居、およ
び環境要因（情報化）の各変数は、事業継承 意志に対して統計的に有意である。

表4 重回帰分析

\begin{tabular}{|c|c|c|c|c|}
\hline & \multicolumn{2}{|c|}{ Model 1} & \multicolumn{2}{|c|}{ Model 2} \\
\hline 独立変数 & 回帰係数 & $\mathrm{t}$ 值 & 回帰係数 & $\mathrm{t}$ 值 \\
\hline 家族従業者数 & $0.161 b$ & 2.201 & & \\
\hline 創業年数 & $0.061 \mathrm{c}$ & 1.653 & $0.063 c$ & 1.769 \\
\hline 家業意識 & $0.550 a$ & 5.565 & $0.524 a$ & 5.356 \\
\hline \multicolumn{5}{|l|}{ 家族財産意識 } \\
\hline 情報化 & $0.386 a$ & 4.641 & $0.381 a$ & 4.654 \\
\hline \multicolumn{5}{|l|}{ 立地条件 } \\
\hline \multicolumn{5}{|l|}{ 需要水準 } \\
\hline \multicolumn{5}{|l|}{ 競争要因 } \\
\hline 経営成果 & $0.170 \mathrm{c}$ & 1.768 & & \\
\hline \multicolumn{5}{|l|}{ 売上高規模ダミー } \\
\hline 親子同居ダミー & $0.283 c$ & 1.855 & $1.506 a$ & 3.750 \\
\hline \multicolumn{5}{|l|}{ 職住一致ダミー } \\
\hline 家業意識 $*$ 経営成果 & - & - & & \\
\hline 家業意識 $*$ 家族従業員数 & - & - & $0.044 a$ & 2.797 \\
\hline 家業意識＊親子同居ダミー & - & - & & \\
\hline 家業意識＊職住一致ダミー & - & - & & \\
\hline 家族財産意識 $*$ 経営成果 & - & - & $0.054 \mathrm{~b}$ & 2.576 \\
\hline 家族財産意識 $*$ 家族従業者数 & - & - & & \\
\hline 家族財産意識 * 親子同居ダミー & - & - & $-0.325 a$ & -3.336 \\
\hline 家族財産意識＊職住一致ダミー & - & - & & \\
\hline 自由度調整済みR ${ }^{2}$ & \multicolumn{2}{|c|}{0.281} & \multicolumn{2}{|c|}{0.313} \\
\hline F值 & \multicolumn{2}{|c|}{13.977} & \multicolumn{2}{|c|}{14.197} \\
\hline 標本数 & \multicolumn{2}{|c|}{294} & \multicolumn{2}{|c|}{294} \\
\hline
\end{tabular}

1）十、一の符号は影響の方向を示している。なお、スケールの方向は調整を既に行い、符号はそのまま解釈し てよいものになっている。

2）自由度調整済みR²は、ステップワイズ回帰推定式のなかで最大の值を取り上げている。

3） cは10\%以内での統計的有意性、bは5\%以内での統計的有意性、aは1\%以内での統計的有意性を示す。

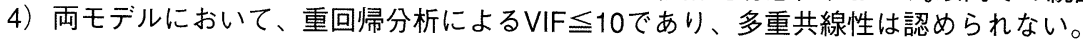

\section{6. 考察}

ここでは商店経営特性 (家族要因)、経営成 果が商店経営者の事業継承意志に影響を及ぼ すという単純な因果関係に対する実践的含意 ではなく、事業継承意志に対して、商店経営 特性が、家族理念意識（家族財産意識、家業 意識）という媒介変数に依存し、その有効性 を発揮するということの実践的意味を検討す
る。

第 1 に、商店経営者の家業意識が高くなる ほど、家族従業者の存在が事業継承意志の高 揚に貢献するということである。家族従業者 の存在が商店経営者の事業継承意志の高揚に 寄与する。しかし、商店経営者の家業意識の 度合いによって、家族従業者が多く参加する ことが事業継承意志に与える影響は異なる。 
商店経営者の家業意識が低くなると、商人家 族が商売に直接関わっているとしても家族に 商店を継がせたいという気持ちは生じないが、 家業意識が高くなると、商人家族が商売に直 接関与することによって、子供に家業を継が せたい気持ちが高揚する。商店にとって重要 な資源である家族を失うこと、すなわち、家 族という労働資源の枯渴は、家業意識が強い 商人に打いて、子供に事業継承させたいとい う意志の減退を招いたということがわかる。

第 2 に、家族財産意識が高くなるほど、商 店経営者が子供と別居することがより事業継 承意志の高揚に貢献することである。この結 果に対しては様々な理由が推測される。まず、 商店経営者が子供と同居している場合は、商 人家族は日常生活をともにすることから、家 族の連帯意識や絆は十分に保持されている。 したがって、家族財産意識の高揚は、改めて 家族の連帯意識や紏を強める要因にはならな い。これとは逆に、商店経営者と子供が別居 する場合は、家族のつながりが弱い。した がって、家族財産意識の高揚は、商人家族間 の関係や紏を強めるあるいは取り戻すために、 商店経営者の事業継承意志の高揚に有効な要 因になりうる。

第 3 に、商店経営者の家族財産意識が高く なるほど、商店の経営成果が事業継承意志の 高揚に貢献するということである。財産の管 理者として商店経営者は、経営成果が悪化す ると、財産として商店の経済的価值が下がる と予想する。したがって、家族財産意識が高 い商店経営者の場合、商店経営成果の好調さ が家族資産として商店の経済的価值を高くす る、あるいは商店経営の展望が良好であると いう期待感を高め、事業継承意志の高揚につ ながる。これとは逆に、経営成果が低くなる ことは商店経営の展望に悪い影響を及ぼし、 事業継承意志を下げることになる。商店経営
者の家族財産意識が低くなれば、経営成果の 動向は、事業継承意志にはあまり有効な要因 ではない。すなわち、家族財産意識が高くな る場合、商店の経営成果が良好になると、商 人家族の生計維持や安定的な収入を得られる 可能性が高くなり、家族財産として子供に商 店を継がせたい意志がより強くなることが予 想され、後継者を育成したいという事業継承 意志の高揚につながる。

\section{7. 限界および課題}

本節では、本稿で今まで行われた商店経営 者の事業継承意志に関する実証分析に対する 限界と今後の研究課題について述べる。その 後、本稿で行われた小売業商店における事業 継承に関する議論が、小売業研究におけるい かなる課題を残すのかについて述べる。

\section{7-1. 本稿の限界}

本稿で行われた商店経営者に関する事業継 承意志に関する実証分析にはどのような妥当 性を疑わせる問題点があるのかを、つぎの 3 点で要約できる。

第 1 に、外的妥当性に関する問題である。 「商店経営に関する調査」という質問題目の上 で、事業継承意志に関する調査が実際された 対象は、広域的商店街を除く隣接消費者に頼 る近隣商店街に属する兵庫県の商店経営者で あった。神戸市の商店街は、阪神大震災で地 域コミュニティが破壊し、商店街も被害を受 けた地域でもある ${ }^{16}$ 。

第 2 に、内的妥当性に関する問題である。こ れに加えて、環境要因という概念に関する指 標の問題である。環境要因で導入されている 指標は、需要水準、情報化、立地条件であっ た。その指標の中、情報化という指標に関す る問題点を指摘しなければならない。本稿で は小売業に打ける技術変化を情報化のみに 
絞って測定しているが、中小小売業における 技術の変化は情報化に限って行なわれるので はなく、商品属性の物理的差異から生じる商 品保管、加工技術の変動や需給調整に関する 技術的変化も含まれるべきであったと思われ る。この点については、今後は環境要因に関 する指標の精緻化および拡張を計り、事業継 承意志に対する因果関係をみる必要性がある。

第 3 に、本稿の射程が、商店経営者の事業 継承意志を問う際に、いくつかの重要な側面 にまで及んでいないことである。まず、重要 な変数と考えられる商店の所有関係を取り入 れていないため、商店所有と事業継承意志と の関係の解明にまで及んでいない点が指摘で きる。すなわち、本稿の分析枠組みは、既存 研究における事業継承の議論を中心に設定さ れたため、商店所有という変数の導入を試み ていなかった。したがって、今後質的な拡が りを確保する試みとして、商店の所有関係に 関する指標の開発を通じて、事業継承研究の 分析枠組みの構築が必要とされるところであ る。つぎに、商店経営者の家商分離意識が事 業継承意志にどのような影響を及ぼすのかに まで分析が及んでいない点である。家商分離 意識の概念が多義的であるため、質問票に準 備された家商分離意識を示す指標間の内的収 束性がみられなかった。したがって、「家商分 離意識」という概念に対する豊富な指標開発 にいたらなかった点については、今後の課題 としたい。

\section{7-2. 今後の課題}

本稿で示した事業継承に関する分析枠組み の限界に起因する今後の課題を提示する。第 1に、本稿の研究は、商店の後継ぎとなる商人 家族を対象にし、商店の後継ぎになりたいと いう意志にはどのような要因が働いているの かについて更なる検討する必要がある。第 2
に、商店街のまちづくり研究や流通政策研究 への展開である。商店街の維持、発展を阻害 する問題として、後継者問題を現場の商店経 営者や、商業研究者をいかに取り上げている のかについては本稿の問題意識で述べたとお りでいうまでもない。本稿の研究結果が、商 店街まちづくり研究や流通政策研究に応用さ れることが期待される。第 3 に、家族商人と コミュニティの関係が事業継承にどのような 影響を及ぼすのかについての研究が必要と考 えている。本稿では商人家族の内部要因と事 業継承の関係に限定しているが、商人家族と コミュニティの関係は更なる考察すべき課題 であることを強調して本稿を終らせることに したい。

\section{〈謝辞〉}

本稿の作成にあたり、神戸大学大学院経営 学研究科石井淳蔵先生、高嶋克義先生、黄磷 先生、流通科学大学崔相鐵先生、慶應義塾大 学井上哲浩先生、『流通研究』のアリア・エ ディターおよびレビュアーの先生方、東アジ アの小売商業と家族従業研究会のメンバーの 方々から貴重なコメントを頂きました。ここ に記して深く打礼申し上げます。また、本稿 は、科学研究補助金 (基盤研究 A) 「東アジア における小売商業と家族從業経営に関する実 証研究」(課題番号 17203030)の助成を受けて 行われたものである。

\section{〈参考文献〉}

Davis, P. S., \& Harveston, P. D.(1998). The Influence of the Family on the Family Business Succession Process: A Multi-Generational Perspective. Entrepreneuship Theory and Practics, Spring, 31-53.

荒川祐吉（1962）『小売商業構造論』、千倉書房。 荒川祐吉（1969）『商業構造と流通合理化』、千倉 
書房。

石井淳蔵 (1979)「小売商業構造の理論的・実証的

研究」、『同志社商学』、第 31 巻第 1 号、100-155 頁。

石井淳蔵 (1981)「小売商業構造の規定要因につい

て」、マーケティングジャーナル』、第1号、8392 頁。

石井淳蔵（1996）『商人家族と市場社会一もうひ とつの消費社会論』、有斐閣。

石井淳蔵・高室裕史・柳到亨・横山斉理 (2007)「小 売商業における家業継承概念の再検討一日韓比 較研究を中心にして一」、『国民経済雑誌』、第 195 巻第 3 号、17-32 頁。

石原武政（2000）『まちづくりの中の小売業』、有 斐閣。

石原武政（2004）「中小小売業 一過小・過多構造 の動態一」、石原武政・矢作敏行編著『日本の流 通 100 年史』、有斐閣。

石原武政 (2006)『小売商の外部性とまちづくり』、 有斐閣。

石原武政・石井淳蔵（1992）『街づくりのマーヶ ティング』、日本経済新聞出版社。

石原武政・石井淳蔵（1995）「被災地小売業復興の

課題」、『BUSINESS INSIGHT』、32-41 頁。

糸園辰雄（1975）『日本中小商業の構造』、ミネル ヴァ書房。

上野千鶴子（1994）『近代家族の成立と終焉』、岩 波書房。

河村雷雨 (1988)『現代社会学序説』、嵯峨野書院。 坂田博美 (2006)『商人家族のエスのグラフィ— 零細小売商における顧客関係と家族従業一』、関 西学院大学出版部。

杉岡直人 (1994) 「家族経営の変革と継承」『家族 農業家業経営の変革と継承』、農山漁村文化協 会。

鈴木安昭（1999）『新・流通と商業』、有斐閣。 鈴木安昭（2001）『日本の商業問題』、有斐閣。 坪内玲子（2001）『継承の人口社会学一誰が「家」
を継いだか一』、ミネルヴァ書房。

林 周二（1962）『流通革命』、中公新書。

高嶋克義（1997）「生業志向のマーケティング行動

一資源ベース視点による考察一」『国民経済雑

誌』、第 176 巻第 1 号、47-60 頁。

高嶋克義（2002）『現代商業学』、有斐閣。

高室裕史・石井淳蔵（2005）「小売業における家族

従業の分析枠組み一東アジアでの国際比較研究

にむけて一」、『国民経済雑誌』、第191巻第4号、 1-20 頁。

田村正紀 (1973)「都市圏小売システム」、『国民経 済雑誌』、第 128 巻第 1 号、73-97 頁。

田村正紀（1981）『大型店問題』、千倉書房。

田村正紀（1986）『日本型流通システム』、千倉書 房。

中野卓(1978）『商家同族団の研究』、未来社。

中野 卓 (2003)「商業経営の主体一商家とその

同族組織一」、永原和子編著『家業と役割』、吉 原弘文館。

中野 安 (1989)「1980年代日本の小売業」、糸園 辰雄編著『現代資本主義と流通』、ミネルヴァ書 房。

中根千枝 (1967)『タテ社会の人間関係』、講談社。 永原和子・義江明子（2003）『相続と財産』、吉川 弘文館。

野口智雄（1987）『現代小売流通の諸側面』、千倉 書房。

三戸 公 (1983)「日本的経営と「家」」『組織科学』、 Vol17,No.1、10-18頁。

牟田和恵（1996）『戦略としての家族 一近代日本 の国民国家形成と女性一』、新曜社。

森岡清美・望月崇（1983）『新しい社会学』、培風 館。

安岡重明 (1998)『近世商家の経営理念・制度・雇 用』、晃洋書房。

矢作敏行（1996）『現代流通』、有斐閣。

山田昌弘（1994）『近代家族のゆくえ』、新曜社。 米村千代 (1996)「経営体としての家族」、『〈家族〉 
の社会学』、岩波書房。

米村千代（1999）『「家」の存続戦略』、剄草書房。 横山斉理 (2006)「小売商業集積における組織的活 動の規定要因についての実証研究」、『流通研 究』、第 9 巻第 1 号、41-55 頁。

横山斉理・柳到亨・高室裕史・石井淳蔵 (2006)「中 小小売商業のありようと家族従業の関係につい ての研究一神戸市の商店街調査を中心に一」、 『神戸大学大学院経営学研究科Discussion Paper』、 $2006 \cdot 10$ 。

柳到亨 (2005)「家族従業構造変化の要因分析」、 『六甲台論集 一経営学編一』、第52巻第2号、1728 頁。

柳 到亨 (2006)「事業継承意志の高揚に関する決 定要因分析」、国民経済雑誌』、第194巻第5号、 91-113頁。

\section{〈注〉}

1 個々の商店にとって後継者がいないことは、商 店の存廃に繋がる。そのミクロ的な商店の動向 は、マクロ的な帰結としての日本小売業の存廃 と決して無関係ではない。いわゆる、ここでい う「後継者難」というのは、流通構造の合理化 の次元あるいは地域的・社会的問題の次元で語 る理論家における問題ではなく、あくまでも商 店街の現場に携わっている商店構成員の経営課 題としての問題である。したがって、現場の問 題意識として、個々の商店の後を継ぐ後継者を いないことを「後継者難」と呼ぶことにしよう。

2 石井 (1996) は、家族財産という家族理念が事 業継承を確実にすると述べている。引用する と次のようである。「「家にある財産は、家族と は切り離しできない」という概念、つまり「家 族財産」概念である。それは、「財産は、家族の 特定の誰かの所有物ではなく、家族全員の所有 物だ」という規範である。その背景には、家族 を支配するものとして、伝統的家父長の権力で はなく、家族という理念がある。そしてそうし
た概念が、商人家族における夫婦間での無償 （あるいは一定の給与を決めない形で）の雇用 を可能にし、家族内世代間での事業あるいは財 産の承継を確実なものとする」(278～279頁)。

3 石井（1996）の 29 頁から引用。

4 石井（1996）の 5～17頁を参考。

5 石井 (1996) の41頁を参照せよ。示されている データから 1960 年代以降の商店主の世帯規模 は縮小の一途を巡っていることがわかる。

6 石井（1996）は、家商分離が家族労働資源の枯 渴させる契機であるとして次のように述べてい る。「「家商分離」傾向は、決して街の商店経営 が悪化し、店舗数が減少するという「街の商店」 の急速な構造不況業種化と無縁ではありえない だろう。街の商人にとって頼るべき貴重な経営 資源であった家族資源が、家商分離や家族規模 縮小によって枯渇する傾向をみせてきたことが 第 1 である」(30 頁)。

7 山田（1994）においても、近代家族は愛情であ ると指摘している。山田 (1994) の研究課題は、 「家族」と「愛情」の関係性に対する特に夫婦間 の愛情やセクシュアリティーに関する社会学的 考察であった。

8 田村（1973）、石井（1981）を参照すること。

9 田村 (1986) は国際小売商業比較からみて規模 の経済が生産性に差異を生むことを指摘してい る $(41$ ～47頁)。田村（1986）において、規模 の経済と生産性との関係は、次の 2 点で整理す ることができる。第 1 に、商店規模格差（従業 者数）によって、従業者一人当たりの販売額で 測定された労働生産性が異なるという。すなお ち、従業者数が多い規模階層は、従業者数が少 ない規模階層に比べて労働生産性が高くなって いることである。第 2 に、売場面績規模格差に よって $1 \mathrm{~m}^{2}$ 当たりの販売額が異なるということ を調べた。この分析の結果は、売場面積生産性 については必ずしも規模格差が関係することは いえないということを示した。田村（1986）の 
規模格差と生産性との関係を検討することによ る日本小売業構造の分析は、先駆的な研究であ る。この見解に従えば、労働生産性は大規模商 店が高く、売場面積生産性は小規模商店が高い という結論に導かれる。つまり、商店の規模が 大きくても、生産性が高いとはいえない。しか し、従業者規模格差によって労働生産性という 商店経営成果が異なるという指摘は、商店規模 によって商店の経済的報酬が異なることを意味 する。もし、この論理が正しければ、商店規模 が大きくなれば、事業継承意志が高くなる可能 性は排除できないと考えられる。

10 田村（1981）、192〜195頁を参照すること。

11 なぜならば、商店経営者の年間売上高を実際の 数字で得ることが非常に難解な課題であるた め、田村（1981）のいう売上高成長速度を商店 経営者が認識する年間売上高の変動に差し替え た。

12 本稿で何回も繰り返していうが、石井（1996） がいう日本の家族の理念を次のように述べてい る。「抢そらくは、「わが国の家族」を根本的に 特徴づける要因は、なおわれわれの生活を支配 する基本的規範であり続けているように見え る。商人であれ、サラリーマンであれ、わが国 の家族を根本的に特徵続ける要因とは、困10-1 の考えにしたがって言えば、家族従業の本質的 定義部分に示される、「家にある財産は、家族 とは切り離しできない」という概念、つまり 「家族財産」概念である。それは、「財産は、家 族の特定の誰かの所有物ではなく、家族全員の 所有物だ」という規範である」(278〜 279頁)。

13 質問票の調査を実施する商業集積の選定および 質問票の配布・回収は、神戸市産業財団の協力 を頂き、行なわれた。神戸市商店集積における 地域特徴は、第 1 に、1995年の阪神大震災によ り調査対象になった商店街の $45.4 \%$ が被災を受 けて、その以降復興へ向っている点である（石 原・石井 1995）。第 2 に、日本の全国都市のな
か、商店数では第 6 番目、年間販売額では第 8 番目の小売業規模を示しており、比較的に大規 模都市に属している（平成 14 年現在、『商業統 計からみた神戸商業』神戸市産業振興財団)。第 3 に、調査が行われた商店街は、広域的商店地 ではなく、隣接する地域消費者を主顧客とする 近隣商店地である。神戸市に限定して調査を 行った理由は、全国に分布する商店経営者を対 象にした質問調查における経済的、時間的コス トの限界を抱えるためであったが、このような

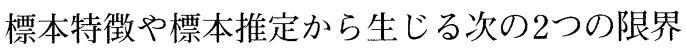
をいわざるを得ない。第 1 に、神戸市が日本小 売業を代表するサンプルであるとは、必ずしも いえないことである。第 2 に、調査対象サンプ ルの選定に関する手続きは、定量調査における 信頼性の確保の側面で不備があることである。 したがって、このような限界から、本研究の目 的は、神戸市の商業集積の実態分析を目指すも のではなく、あくまでも設定した仮説における 概念間の関係を究明することにとどめておく。

14 第 1 に、標本をみると 50 代以上の殆どの商店経 営者が、第 1 子の年齢が18歳を超えていること から、事業継承問題をより現実的に考えている と思われる。すなわち、商店経営者の子供が 18 歳を超えると、彼あるいは彼女が職業選択に迫 られることになり、商店経営者も子供を商店の 後継ぎするか否かについて熟考する。まず、 親子同居に関しては、18歳未満の子供がいる商 店経営者は、子供と同居しているケースが多数 あることや、18未満の子供は親と同居するか否 かの選択肢を持たないと予想され、親子同居と いう指標の事業継承意志に対する有効性の検証 は限界を抱えることになる。つぎに、家族従業 者に関しては、幼い子供は従業員として直接、 商売に従事する可能性は低いことが予想され、 親子同居と同様に仮説検定に困難が生じると考 えられる。

15 予想とは違って、仮説とは逆の結果がえられ 
た。この結果を詳しく検討するため、親子同居 と家族財産意識の交互効果に関する回帰分析の 推定結果をみることにする。推定結果は、以下 の式のようである。すなわち、 $\mathrm{Y}=2.943+0.256 \mathrm{X}+$ $0.433 Z-0.326 \mathrm{XZ}(\mathrm{X}=$ 家族財産意識、 $\mathrm{Z}=$ 親子 同居ダミー、Y=事業継承意志、 $X Z=$ 交互作用項） である。親子別居の場合は、家族財産意識の偏 回帰係数 (0.256) が事業継承意志に対する影響 力を示す。したがって、親子別居の場合は、家 族財産意識が高くなることによって事業継承意 志が高揚される。しかし、親子同居の場合は、 家族財産意識の偏回帰係数を交互作用項の偏回 埽係数と足した值 $(-0.07)$ が事業継承意志に対 する影響力を示すことになる。したがって、親 子同居の場合は、家族財産意識が高くなること によって、事業継承意志は若干弱化する。すな わち、親子同居の場合、家族財産意識が事業継 承意志の高揚に影響を及ぼす有効性はないこと がいえる。

16 石原・石井(1995)を参照すること。 